ROCZNIKI TEOLOGICZNE

Tom LXVIII, zeszyt $10-2021$

DOI: https://doi.org/10.18290/rt.216810.2

MONIKA PARCHOMIUK

\title{
SATYSFAKCJA I WYMAGANIA W ROLI MATKI I OJCA DZIECKA Z NIEPEŁNOSPRAWNOŚCIA
}

\author{
SATISFACTION AND DEMANDS IN THE ROLE OF MOTHER AND FATHER \\ OF A CHILD WITH DISABILITY
}

\begin{abstract}
A b s t r a c t. The article presents the results of the author's own research, aimed at establishing the relationship between the demands of the parental role in mothers and fathers raising a child with a disability and their satisfaction with parenthood. The analyzes also took into account the age of the child and the type of disability. The author's own measures were used: the Parenting Experience Scale, the Parental Role Demands Scale, and a questionnaire. Ultimately, material obtained from 83 mothers and 67 fathers was analyzed. Based on the results of multiple regression analysis, similar trends were found in the group of mothers and fathers, showing the contribution of demands to shaping satisfaction scores. More frequent demands of the role were usually accompanied by lower satisfaction in its various dimensions. Only contradictions in the role of the parent created positive associations with the dependent variable in the regression models. The type of child's disability was significant only for shaping the results of role demands and one of the aspects of fathers' satisfaction, while the age variable was significant for external expectations of the maternal role.
\end{abstract}

Keywords: parental roles; parental satisfaction; parental demands; autism spectrum disorders; intellectual disabilities

\section{WPROWADZENIE}

Rola społeczna jest konstruktem złożonym i dynamicznym. O jej złożoności decyduje szereg zachowań, zarówno determinujących ją (względnie

Dr hab. MONIKA PARCHOMIUK, prof. UMCS - Instytut Pedagogiki, Uniwersytet Marii Curie-Skłodowskiej w Lublinie; e-mail: monika.parchomiuk@mail.umcs.pl; ORCID: https:// orcid.org/0000-0002-0756-4242. 
trwałych), jak i niedeterminujących (zmiennych), ponadto wielozakresowość czynników warunkujących. W kontekście roli rodzicielskiej szczególnie przydatne wydaje się ujęcie roli, o którym pisze M. Chodkowska ${ }^{1}$ : „Rola stanowi [...] swoisty typ relacji społecznych, system stosunków pomiędzy działaniami przypisywanymi poszczególnym członkom grupy a wzorami grupowymi wyrażającymi potrzeby i oczekiwania tej grupy”. Traktowanie roli w aspekcie relacyjnym pozwala ująć jej dynamikę, ale także zmienność kontekstu, w jakim jest realizowana. Role rodzicielskie sa podejmowane w określonych uwarunkowaniach społeczno-kulturowych, z których wywodzą się wzory, wartości i oczekiwania. Głównym źródłem wzorów ról jest socjalizacja ${ }^{2}$, jednak w dużej mierze jednostka kształtuje je poprzez osobiste doświadczenia.

Rozpatrując istotę roli rodzicielskiej w sytuacji niepełnosprawności dziecka, koncentrujemy się przede wszystkim na ich specyfice behawioralnej, na którą składa się szereg dodatkowych zadań i działań z nimi związanych ${ }^{3}$. Mamy tu do czynienia z poszerzeniem zadań w zakresie funkcji opiekuńczo-wychowawczej, ale także znacznym wydłużeniem ich realizacji w czasie. Obie role, tj. matki i ojca, choć w nierównym stopniu dla obu płci, zostają rozbudowane o zadania wymagające nowych i niestandardowych dla ról rodzicielskich kompetencji ${ }^{4}$.

W sytuacji niepełnosprawności dziecka mogą następować również inne zmiany w obszarze ról rodzicielskich, obejmujące system przekonań oraz wartości, ale także w zakresie społecznych oczekiwań. Są one ważne dla powstawania modelu „dobrego rodzica”. W rodzinach z dzieckiem niepełnosprawnym odnotowano silniejsze tendencje wskazujące na występowanie tradycyjnych modeli, zakładających prymat matki w szeroko rozumianej opiece nad dzieckiem niepełnosprawnym oraz ojca jako osoby odpowiedzialnej za pozyskanie środków na utrzymanie rodziny ${ }^{5}$. Niewątpliwie ważny jest tutaj stopień akceptacji tradycyjnie ukierunkowanego modelu przez oboje

\footnotetext{
${ }^{1}$ Maria Chodkowska, „Teoria ról społecznych a badania socjopedagogicznych problemów zdrowia i choroby", Chowanna 45(2002): 41.

${ }^{2}$ Chodkowska, Teoria ról społecznych, 41.

${ }^{3}$ Chodkowska, Teoria ról społecznych, 47-48.

${ }^{4}$ Por. Valerie Leiter, Marty W. Krauss, Betsy Anderson, Nora Wells, ,The consequences of caring. Effects of mothering a child with special needs", Journal of Family Issuess 25(2004): 382; Hedda Meadan, Julia B. Stoner, Maureen E. Angell, „Fathers of children with autism: perceived roles, responsibilities and support needs", Early Child Development and Care 185 (2015): 1679; Alice Schippers, Michel Berkelaar, Minne Bakker, Geert Van Hove, „The experiences of Dutch fathers on fathering children with disabilities: 'Hey, that is a father and his daughter, that is it"', Journal of Intellectual Disability Research 64(2020): 449.

${ }^{5}$ Meadan, Stoner, Angell, "Fathers of children with autism," 1679.
} 
partnerów. Niesie on pewne ryzyko samoograniczeń rodziców, co na poziomie empirycznym udowodniono przede wszystkim w badaniach z udziałem matek, wskazując na tendencje, takie jak rezygnacja $\mathrm{z}$ innych ról (m.in. zawodowych), silne skoncentrowanie fizyczne i psychiczne na potrzebach dziecka z niepełnosprawnością oraz niezdolność do dzielenia się opieką nad nim 6 . Należy jednak zauważyć, że udział ojców w opiece nad dzieckiem z niepełnosprawnością może być szerszy, a partnerzy w związku rodzicielskim moga dzielić się obowiązkami w zależności od potrzeb ${ }^{7}$.

Rodzicielskie role moga być źródłem konfliktów, w tym wynikających na tle godzenia zadań pochodzących z innych ról (np. zawodowych), realizowanych w stosunku do innych osób w rodzinie (np. dzieci pełnosprawnych), powstających $\mathrm{w}$ efekcie niezgodności między osobistymi przekonaniami i wartościami a społecznymi oczekiwaniami ${ }^{8}$. Te ostatnie moga dotyczyć osiągnięć dziecka z niepełnosprawnością zarówno aktualnych, jak perspektywicznych, i pozostają w ścisłym związku z oceną jakości rodzicielstwa, którego wskaźnikiem są kompetencje oraz zachowania dziecka. Potrzeby dziecka z niepełnosprawnością, tak rozwojowe, wynikające z danej fazy życia, jak i specjalne związane z rodzajem i stopniem ograniczeń zdrowia i sprawności, poszerzają znaczenie spektrum społecznych relacji, w jakie uwikłani są rodzice. Chodzi tutaj zwłaszcza o kontekst specjalistyczny. Specjaliści, z którymi współpracują rodzice, są ważnym źródłem informacji zwrotnej odnoszącej się do jakości rodzicielskich poczynań ${ }^{9}$. Oczekiwania zewnętrzne mogą być niespójne z tymi, jakie prezentują rodzice, budujący obraz dziecka z niepełnosprawnością na podstawie własnych doświadczeń ${ }^{10}$. Społeczny kontekst ro-

\footnotetext{
${ }^{6}$ Leiter, Krauss, Anderson, Wells, "The consequences of caring," 399; Julia Sheran, Stuard Todd, "Maternal employment and family responsibilities: the perspectives of children with intellectual disabilities," Journal of Applied Research in Intellectual Disabilities 13(2000): 110-129; Shirley A. Sitimin, Amily Fikry, Zulhabri Ismali, Norashikin Hussein, „Work-family conflict among working parents of children with autism in Malaysia", Procedia Computer Science 105(2017): 345.

${ }^{7}$ Por. Meadan, Stoner, Angell, "Fathers of children with autism," 1683.

${ }^{8}$ Theresa J. Brown, "Work family conflict among parents of atypically developing children: exploring the impact of worker, work, and child factors", Journal of Child and Family Studies 23(2014): 854-862; Theresa J. Brown, Kenneth E. Sumner, "Cross national examination of work family in parents of children with disabilities using a bioecological model," Child \& Youth Care Forum 48(2019): 703-717; Chodkowska, „Teoria ról społecznych”, 47-48.

${ }^{9}$ Penelope M. Karney, Tim Griffin, "Between joy and sorrow: being a parent of a child with developmental disability," Journal of Advanced Nursing 34(2001): 582-590.

${ }^{10}$ Yoon-Joo Lee, Hye J. Park, Susan L. Recchia, "Embracing each other and growing together: redefining the meaning of caregiving a child with disabilities," Journal of Child and
} 
dzicielstwa bywa istotnym źródłem zasobów, w tym psychicznych i instrumentalnych, ale może także rodzić trudności w realizacji roli matki czy ojca. Ze środowiska mogą płynąć postawy medykalizujące niepełnosprawność, ograniczające perspektywy rozwojowe dziecka, stygmatyzujące i nieakceptujące jego trudności ${ }^{11}$. Negatywne postawy oraz niedostosowanie czy brak usług prowadzą do izolacji i samoizolacji rodziny, jej osamotnienia w radzeniu sobie z trudnościami, a w przypadku rodziców poczucia stałego podlegania kontroli i ocenie ${ }^{12}$. Przejawem rodzicielskiej adaptacji w roli matki/ojca dziecka z niepełnosprawnością, która może wymagać czasu i doświadczenia, będzie zdolność radzenia sobie z negatywnymi aspektami środowiskowymi, między innymi poprzez wypracowanie i utrwalenie własnego obrazu możliwości i ograniczeń dziecka oraz dążenie do realizacji jego potrzeb z tym związanych ${ }^{13}$. Osiągnięcia dziecka, zaprzeczające pierwotnym rokowaniom specjalistów czy przekonaniom niespecjalistów, mogą być źródłem dumy, satysfakcji, szczęścia oraz poczucia osobistego sukcesu ${ }^{14}$.

Family Studies 24(2015): 3667 n.; Carol A. Potter, “'I accept my son for who he is - he has incredible. Character and personality': fathers' positive experiences of parenting children with autism," Disability \& Society 31(2016): 949.

${ }^{11}$ Deborah Cairns, Debbie Tolson, Jane Brown, Cris Darbyshire, "The need for future alternatives: an investigation of the experiences and future of older parents caring for offspring with learning disabilities over a prolonged period of time," British Journal of Learning Disabilities 41(2012): 76; Jakub Niedbalski, „,Realizowanie ról rodzicielskich i konstruowanie tożsamości rodziców dziecka z niepełnosprawnością intelektualną", Studia Socjologiczne 3(2019): 163.

${ }^{12}$ Sara E. Green, “'We're tired, not sad"”: Benefits and burdens of mothering a child with a disability", Social Science \& Medicine 64(2007): 154.

${ }^{13}$ Briana S. Nelson Goff, Kale J., Monk, Juliana Malone, Natira Staats, Allison Tanner, Nicole P. Springer, "Comparing parents of children with Down syndrome at different life span stages", Journal of Marriage and Family 78(2016): 1138; Abu S. Nurullah, "II's really a roller coaster": experience of parenting children with development al disabilities," Marriage \& Family Review 49(2013): 420; Hye J. Park, Grace H. Chung, "Multifaceted model of changes and adaptation among Korean mothers of children with disabilities," Journal of Child and Family Studies 24(2015): 924; Amy Patric-Ott, Linda D. Ladd, "The blending of Boss's concept of ambiguous loss and Olshansky's concept of chronic sorrow: a case study of a family with a child who has significant disabilities", Journal of Creativity in Mental Health 5(2010): 78.

${ }^{14}$ Lucyna Bakiera, Żaneta Stelter, ,Rodzicielstwo z perspektywy rodziców dziecka pełnosprawnego i niepełnosprawnego intelektualnie", Roczniki Socjologii Rodziny 20(2010): 140; Garry Hornby, "A review of fathers' accounts of their experiences of parenting children with disabilities", Disability, Handicap and Society 7(1992): 366-370; Tim Stainton, Hilde Besser, "The positive impact of children with an intellectual disability on the family", Journal of Intellectual and Developmental Disability 23(2008): 61; Kumiko Takataya, Yoko Yamazaki, Eriko Mizuno, "Perceptions and feelings of fathers of children with Down Syndrome", Archives of Psychiatric Nursing 30(2016): 546. 
Obraz rodzicielskich doświadczeń w sytuacji wychowania dziecka z niepełnosprawnością jest bardzo złożony i niejednoznaczny, co wiąże się z wyżej opisanymi zagadnieniami. Badania wykazują, że dysponując pewnymi zasobami osobistymi i środowiskowymi matki i ojcowie z różną jakością realizuja swoje role rodzicielskie ${ }^{15}$. Obecnie podkreśla się konieczność uwzględniania dwóch wymiarów rodzicielskiego funkcjonowania w rolach, tj. negatywnego i pozytywnego. Nie można ich traktować jako wykluczających się, stanowią one raczej dwie względnie niezależne dymensje. Obie z nich są ważne przy rozpatrywaniu rodzicielskiej adaptacji do życia z dzieckiem z niepełnosprawnością.

\section{BADANIA WŁASNE}

Wielość zadań oraz konieczność ich realizowania przy współudziale innych osób, dostarczających określonych ocen rodzicielskich poczynań, poszerza spektrum doświadczeń matek i ojców w sytuacji niepełnosprawności dziec$\mathrm{ka}^{16}$. W ich zakresie będą mieścić się zarówno doświadczenia pozytywne, jak i negatywne. W badaniach własnych skoncentrowano się na obu $\mathrm{z}$ nich, sprawdzając wymiar satysfakcji i wymagań (obciążeń) w roli rodzica. Literatura przedmiotu nie dostarcza wyczerpujących teorii i badań wyjaśniających rodzicielską satysfakcję. W empirycznych próbach jej zdefiniowania, czy to u rodziców dzieci pełnosprawnych czy rzadziej niepełnosprawnych, pojawia się ona, obok rodzicielskiej samoskuteczności, jako element szerszego konstruktu rodzicielskiej samooceny ${ }^{17}$. Przyjęty w badaniach własnych sposób oceny satysfakcji z roli rodzicielskiej ma charakter wielowymiarowy, nawiązujący do ujęcia satysfakcji z pracy oraz satysfakcji z życia. Założono bowiem, że doświadczenia w roli rodzicielskiej są złożone i ujawniają się za-

\footnotetext{
${ }^{15}$ Chandra S. Chouchan, Paramjeet Singh, Sunil Kumar, "Assessment of stress and anxiety in parents of children with intellectual disability," Indian Journal of Health \& Wellbeing 7(2016): 502-503; Anna Dąbrowska, Ewa Pisula, "Parenting stress and coping styles in mothers and fathers of pre-school children with autism and Down Syndrome," Journal of Intellectual Disability Research 54(2010): 272-274; Ashlyn L. Smith, Maryann Romski, Rose A. Sevcik, Lauren B. Adamson, Michael R. Barker, "Parent stress and perceptions of language development: comparing Down Syndrome and other developmental disabilities," Family Relations 63(2014): 78 .

${ }^{16}$ Bakiera, Stelter, „Rodzicielstwo z perspektywy rodziców”, 146.

${ }^{17}$ Charlotte Johnston, Eric J. Masch, "A measure of parenting satisfaction and efficacy," Journal of Clinical Child Psychology 18(1989): 167.
} 
równo na poziomie afektywnym, jak i poznawczym ${ }^{18}$. Wielowymiarowość ujęcia satysfakcji polega również na uwzględnieniu różnych aspektów rodzicielstwa, dostarczając w tym względzie swoistej ich hierarchizacji w perspektywie doznawania zadowolenia. Ten sposób ujęcia wydaje się być bardziej rzetelny od globalnych sposobów analizy, w których definiuje się wskaźnik ogólny.

Wymagania (obciążenia) w roli są rozumiane w badaniach własnych jako psychospołeczne i organizacyjne aspekty roli, dla których konieczne jest podjęcie dodatkowego wysiłku, które mogą rodzić trudności ze względu na brak dostatecznych zasobów lub ich wyczerpanie, pojawiające się niejasności oraz konflikty ${ }^{19}$. Koncentrowanie się wyłącznie na rodzicielskich doświadczeniach, bez względu na przyjętą perspektywę analiz, z pominięciem uwarunkowań środowiskowych, w jakich opieka nad dzieckiem jest realizowana, daje niepełny obraz zjawisk ${ }^{20}$. Zasadność uwzględnienia kontekstu potwierdzają dotychczasowe analizy poświęcone rodzicielskim korzyściom i wyzwaniom w sytuacji niepełnosprawności dziecka ${ }^{21}$. W związku z tymi założeniami w projektowanych badaniach, sprawdzając rodzicielską satysfakcję i wymagania (obciążenia), uwzględniono aspekt społecznych oczekiwań oraz ocen. Role rodziców są komplementarne w kontekście wychowania dziecka, a dla ich realizacji ważne są posiadane wzorce, cechy osobowości i doświadczenia, ale też wspomniany kontekst społeczny. Niezbędne wydaje się zatem z tej perspektywy angażowanie w projekt badawczy obojga rodziców.

Celem badań własnych jest stwierdzenie związków między rodzicielską satysfakcją $w$ jej wielowymiarowym ujęciu a wymaganiami (obciążeniami) związanymi $\mathrm{z}$ pełnieniem roli matki/ojca dziecka $\mathrm{z}$ niepełnosprawnością z uwzględnieniem zmiennych, takich jak rodzaj niepełnosprawności dziecka oraz jego wiek. Zakłada się, że wyższa satysfakcja rodzicielska będzie współwystępować z mniejszą częstością wymagań w roli. Badacze piszą o możliwym współwystępowaniu stresu, problemów psychospołecznych i trudności

\footnotetext{
${ }^{18}$ Anna Zalewska, Dwa światy. Emocjonalne i poznawcze oceny jakości i ich uwarunkowania u osób o wysokiej i niskiej i reaktywności (Warszawa: Academica, 2003).

${ }^{19}$ Patricia Voydanoff, "Implications of work and community resources and demands for marital quality,” Journal of Organizational Psychology 9(2004): 277.

${ }^{20}$ Kathryn Knight, "The changing face of the 'good mother': trends in research into families with a child with intellectual disability, and some concerns," Disability \& Society 28(2013): 662.

${ }^{21}$ Niedbalski, „Realizowanie ról rodzicielskich”, 163; Jane P. Sheldon, Mary Oliver, Beverly M. Yashar, "Rewards and challenges of parenting a child with Down syndrome: a qualitative study of fathers' perceptions," Disability and Rehabilitation, accessed April 15, 2021, https://doi.org/10.1080/09638288.2020.1745907
} 
z pozytywną transformacją i wzrostem rodziców, ale także pozytywną percepcją swojego rodzicielstwa ${ }^{22}$. Badania wykazują również, że częstsze relacjonowanie przez rodziców pozytywnych doświadczeń związanych z wychowaniem dziecka z niepełnosprawnością współwystępuje z mniejszym nasileniem doświadczanego stresu ${ }^{23}$.

\section{METODA}

W badaniach zastosowano trzy narzędzia własnej konstrukcji. Skala Doświadczeń Rodzicielskich składa się z dwóch części, z których jedna pozwala zweryfikować stopień subiektywnie ocenianej realizacji potrzeb psychospołecznych rodzica oraz zakres emocjonalnych doznań czerpanych w związku $\mathrm{z}$ wychowaniem dziecka $\mathrm{z}$ niepełnosprawnością (10 twierdzeń), a druga określić satysfakcję z wybranych aspektów rodzicielstwa (28 twierdzeń). Uwzględniono subiektywne oceny rodziców odnoszące się do stopnia realizacji potrzeb psychospołecznych oraz satysfakcji odczuwanej w związku z różnymi wymiarami rodzicielstwa. Analizie poddano aspekt udziału w rozwoju dziecka oraz zadowolenia z jego przebiegu, postaw osób znaczących wobec dziecka, odczuwanej gratyfikacji z własnych poczynań rodzicielskich, ponadto możliwości podejmowania pozarodzinnych form aktywności. Obie części skali mają charakter dyferencjału semantycznego (w części pierwszej skala odpowiedzi od -3: w bardzo małym stopniu, do +3 : w bardzo dużym stopniu; w części drugiej od -3 : bardzo niezadowolony, do +3 : bardzo zadowolony) (informacje nt. współczynników alfa Cronbacha są dostępne u autora).

Skala Wymagań w Roli Rodzicielskiej zawiera 22 twierdzenia opisujące subiektywnie oceniane wymagania (obciążenia) związane z wychowaniem dziecka z niepełnosprawnością. Wymagania te (obciążenia) są sprawdzane w odniesieniu do subiektywnej oceny wystarczalności zasobów potrzebnych do realizacji zadań związanych z rolą, oczekiwań środowiska zewnętrznego odnoszących się do jakości realizacji zadań, przeciążenia zadaniami oraz odczuwanych sprzeczności (konfliktów) wewnątrz roli wynikających z konfrontacji pewnych zobowiązań i oczekiwań zewnętrznych z własnymi przeko-

\footnotetext{
${ }^{22}$ Kate Scorgie, Lorraine Wilgosh, Dick Sobsey, "The experience of transformation in parents of children with disabilities: theoretical considerations," Developmental Disabilities Bulletin 32(2004): 85-90.

23 Adam D. Kayfitz, Marcia N. Gragg, Robert R. Orr, "Positive experiences of mothers and fathers of children with autism," Journal of Applied Research in Intellectual Disabilities 23(2010): 342.
} 
naniami, wartościami czy kompetencjami. Twierdzenia są poddawane ocenie z zastosowaniem 5-stopniowej skali opisującej częstość danego odczucia (od 0 - w ogóle nie do 4 - bardzo często) (informacje nt. współczynników alfa Cronbacha są dostępne u autora). Dane socjodemograficzne zebrano na podstawie kwestionariusza ankiety.

Do grupy rekrutowano pracujących zawodowo rodziców (par rodzicielskich) mających dziecko w wieku 3-18 lat z niepełnosprawnością potwierdzoną orzeczeniem powiatowego zespołu ds. orzekania o niepełnosprawności/ stopniu niepełnosprawności lub poradni psychologiczno-pedagogicznej. Rekrutacja odbywała się za pośrednictwem placówek oświatowych ze wszystkich regionów kraju. Badania zrealizowano drogą pocztową. Szczegółowe informacje są dostępne u autora badań.

Materiał uzyskano od 151 rodzin (par rodzicielskich) wychowujących dziecko $\mathrm{z}$ niepełnosprawnością $\mathrm{w}$ wieku od 3 do 18 roku życia $(\mathrm{M}=9,59$; $\mathrm{SD}=4,43)$. Grupa ta w największym zakresie była reprezentowana przez matki i ojców dzieci z niepełnosprawnością intelektualną $(58$, tj. 38,41\%) oraz z zaburzeniami ze spektrum autyzmu (54, tj. 35,76\%). W mniejszym zakresie znaleźli się $\mathrm{w}$ niej rodzice wychowujący dziecko $\mathrm{z}$ niepełnosprawnością ruchowa $(25, \mathrm{tj} .16,56 \%)$ oraz sensoryczną (wzroku lub słuchu) w normie intelektualnej (14, tj. 9,27\%). Ze względu na nieliczną reprezentację obu tych niepełnosprawności zdecydowano się na uwzględnienie wyników dotyczących rodziców dzieci z niepełnosprawnością intelektualną (NI) oraz z zaburzeniami ze spektrum autyzmu (ASD). Po odrzuceniu braków danych ostatecznie wykorzystano materiał uzyskany od 150 osób, w tym 83 matek oraz 67 ojców (67 par rodzicielskich oraz 16 matek pozostających w związkach małżeńskich/ partnerskich).

\section{WYNIKI}

Matki były w wieku od 30 do 59 lat $(M=41,18$; $S D=6,92)$, ojcowie w wieku od 28 do 61 lat $(\mathrm{M}=43,60 ; \mathrm{SD}=7,73)$. Badane rodziny zamieszkiwały głównie w mieście $(64, \mathrm{tj} .77,1 \%)$. Matki w większości miały wykształcenie wyższe $(47, \mathrm{tj} .56,6 \%)$ oraz średnie-zawodowe bądź ogólne (30, tj. 36,1\%). Najwięcej ojców miało wykształcenie wyższe $(37$, tj. 55,2\%) oraz średnie zawodowe bądź ogólne (31, tj. 46,3\%).

$\mathrm{W}$ badanej grupie znalazły się dzieci z niepełnosprawnością w wieku od 3 do 18 roku życia $(\mathrm{M}=10,15 ; \mathrm{SD}=3,71)$. Dzieci z ASD były starsze w porównaniu do dzieci z NI $\left(\mathrm{M}_{\mathrm{ASD}}=11,45 ; \mathrm{M}_{\mathrm{NI}}=8,69 ; \mathrm{t}=4,28, \mathrm{p}=0,000\right)$. W 56 ro- 
dzinach $(67,5 \%)$ badanych wychowywały się również dzieci pełnosprawne w wieku od kilku miesięcy do 33 lat.

Matki i ojcowie nie różnią się istotnie w zakresie większości aspektów opisujących ich satysfakcję rodzicielską oraz wymagania w rolach (statystyki opisowe zmiennych są dostępne u autora). Stwierdzono, że matki istotnie wyżej oceniają swoje doświadczenia związane $\mathrm{z}$ udziałem $\mathrm{w}$ wychowaniu dziecka (SSII SUW: t=5,63; p=0,000). Różnicę na poziomie zbliżonym do istotnego $(\mathrm{t}=-1,99 ; \mathrm{p}=0,050)$ odnotowano $\mathrm{w}$ przypadku podskali Postawy społeczne wobec dziecka z niepełnosprawnością. Ojcowie uzyskali tutaj wyższy wynik. Żadna z podskal, opisujących rodzicielskie wymagania (obciążenia), nie różnicowała istotnie badanych rodziców.

W grupie matek odnotowano szereg istotnych zależności o umiarkowanej bądź słabej sile i ujemnym znaku pomiędzy poszczególnymi wymiarami satysfakcji oraz wymagań (szczegółowe dane są dostępne u autora). Najwięcej takich zależności dotyczy podskal: Brak wystarczających zasobów w roli; Oczekiwania zewnętrzne oraz Przeciążenie rolą. Słabsze związki wystąpiły w przypadku Sprzeczności w roli. Rodzaj niepełnosprawności dziecka korelował istotnie najczęściej Z wymaganiami, tworząc dodatnie zależności o umiarkowanej i słabej sile. Zależności słabe, ujemne, odnotowano w zakresie zmiennej Rodzaj niepełnosprawności oraz podskal Satysfakcja z udziału w wychowaniu dziecka i Satysfakcja z pozarodzinnych form aktywności. Wiek dziecka nie wszedł $\mathrm{w}$ istotne związki ze zmienną satysfakcji oraz wymagań $\mathrm{w}$ roli.

W grupie ojców odnotowano nieliczne istotne związki w obrębie satysfakcji i wymagań (szczegółowe dane są dostępne u autora). Zaznaczyły się one przede wszystkim w zakresie podskal Brak wystarczających zasobów w roli oraz Oczekiwania zewnętrzne. Tutaj miały jednak najczęściej słabą siłę i podobnie jak u matek - ujemny charakter. Jedynie dwa współczynniki (SSII SRD-WR BZ oraz SSIIUW - WR BZ) wskazywały na umiarkowaną siłę związku. Rodzaj niepełnosprawności dziecka korelował w grupie ojców ujemnie z podskalą Satysfakcja z pozarodzinnych form aktywności oraz dodatnio z dwiema podskalami skali wymagań: Przeciążeniem rolą oraz Sprzecznościami w roli. Zmienna wieku dziecka istotnie i ujemnie korelowała z satysfakcja ojców z pozarodzinnych form aktywności.

W pierwszym etapie w obu grupach włączono do modelu zmienne - rodzaj niepełnosprawności dziecka oraz jego wiek - sprawdzając ich udział w kształtowaniu wyników wymagań jako umownie przyjętego predykatora zmiennej zależnej rodzicielska satysfakcja. Rodzaj niepełnosprawności dziecka okazał się istotny dla wszystkich aspektów wymagań roli matki, poza Oczekiwaniami zewnętrznymi (szczegółowe dane dostępne u autora). W tym przypadku niepełnosprawność 
intelektualna powoduje częstsze, w porównaniu do ASD, poczucie wymagań (obciążeń) związanych z realizacją roli, co przejawia się odczuwanym niedostatkiem zasobów niezbędnych do wykonywania zadań roli [WR BZ: $\mathrm{F}(2,80)=6,04$; $\mathrm{p}=0.004, \mathrm{R}^{2}=0,13, \mathrm{R}^{2}=0,11$ ], doświadczaniem przeciążenia [WR PR: $\mathrm{F}(2,80)=$ 21,$\left.81 ; p=0,000, R^{2}=0,35, R^{2}=0,34\right]$, ale również doznawanymi $w$ niej sprzecznościami [WRSR: $\left.\mathrm{F}(2,80)=14,41 ; \mathrm{p}=0,000, \mathrm{R}^{2}=0,26, \mathrm{R}^{2}=0,25\right]$. W zakresie poszczególnych aspektów wymagań odnotowano zróżnicowany udział zmiennej Rodzaj niepełnosprawności w wyjaśnianiu ich wariancji wzrostu: stosunkowo duży w przypadku przeciążenia rolą (34\%), mniejszy w zakresie doświadczanego przeciążenia (25\%) i niewielki w odniesieniu do zmiennej Brak zasobów do realizacji roli (11\%). Dla oczekiwań zewnętrznych dotyczących sposobów wykonywania roli istotny okazał się wiek dziecka $\mathrm{z}$ niepełnosprawnością [WR OZ: $\left.\mathrm{F}(2,80)=9,39 ; \mathrm{p}=0,000, \mathrm{R}^{2}=0,19, \mathrm{R}^{2}=0,17\right]$. Doświadczanie tego rodzaju wymagań nasila się $\mathrm{z}$ wiekiem. Zmienna wieku wyjaśnia $17 \%$ wariancji wzrostu tego aspektu wymagań matek. W drugim etapie analiz do modelu włączono zmienne związane $\mathrm{z}$ dzieckiem niepełnosprawnym oraz wymagania $\mathrm{w}$ roli, sprawdzając ich udział w kształtowaniu wyników poszczególnych aspektów rodzicielskiej satysfakcji. Wszystkie modele regresji okazały się być istotne. W przypadku satysfakcji, zdefiniowanej w oparciu o subiektywną ocenę realizacji potrzeb psychospołecznych rodzica oraz zakres emocjonalnych doznań czerpanych w związku z wychowaniem dziecka z niepełnosprawnością, model regresji wykazał dobre dopasowanie do danych [SSI: $\mathrm{F}(6,76)=4,26 ; \mathrm{p}=0,001$, $\left.\mathrm{R}^{2}=0,25, \mathrm{R}^{2}=0,19\right]$. Uzyskane tu zestawienie zmiennych, spośród których tylko dwie okazały się być istotne (Oczekiwania zewnętrzne oraz Sprzeczności w roli), wyjaśnia 19\% wariancji wzrostu zmiennej zależnej. Rodzice, którzy rzadziej doświadczają wymagań w postaci społecznych oczekiwań dotyczących jakości roli, ale również ci, którzy częściej przeżywają sprzeczności w związku z jej realizacją, wykazują większą satysfakcję rodzicielską, wyżej oceniając możliwość zaspokojenia własnych potrzeb psychospołecznych w związku z wychowaniem dziecka niepełnosprawnego oraz czerpiąc więcej pozytywnych emocji $\mathrm{w}$ tym procesie. $\mathrm{W}$ istotnym modelu regresji, wyjaśniajacym 15\% wzrostu wariancji zmiennej zależnej, tylko Oczekiwania zewnętrzne okazały się być istotne dla satysfakcji z postępów w rozwoju dziecka [SSIISRD: $\left.\mathrm{F}(6,76)=3,46 ; \mathrm{p}=0,004, \mathrm{R}^{2}=0,21, \mathrm{R}^{2}=0,15\right]$. Częstsze wymagania, odczuwane w tym obszarze roli, są powiązane z niższą oceną postępów rozwojowych dziecka z niepełnosprawnością. Podobny układ zmiennych odnotowano w modelu regresji utworzonym dla zmiennej zależnej Satysfakcja z postaw społecznych obserwowanych wobec dziecka z niepełnosprawnością, wyjaśniającym 14\% zmienności wariancji tej zmiennej [SSIIPS: $F(6,76)=3,28$; 
$\left.\mathrm{p}=0,006, \mathrm{R}^{2}=0,21, \mathrm{R}^{2}=0,14\right]$. Tutaj także częściej odbierane oczekiwania zewnętrzne wobec jakości realizacji roli rodzicielskiej współwystępują z mniejszym nasileniem satysfakcji. W przypadku Gratyfikacji wysiłków rodzicielskich model regresji wykazał dobre dopasowanie do danych [SSIIGWR: $\left.\mathrm{F}(6,76)=5,59 ; \mathrm{p}=0,000, \mathrm{R}^{2}=0,31, \mathrm{R}^{2}=0,25\right]$. Jego moc $\mathrm{w}$ wyjaśnianiu wzrostu wariancji zmiennej zależnej jest wyższa w porównaniu do wcześniej opisanych modeli regresyjnych utworzonych dla innych aspektów satysfakcji matek. W tym przypadku wynosi $25 \%$. Jednak także i tutaj jedynie jedna zmienna - Brak wystarczających zasobów roli - jest istotna dla tego aspektu satysfakcji matek. Częstsze odczucie braku/niedostatku zasobów pozwalających na realizację zadań roli jest powiązane ze słabszymi doświadczeniami zyskania gratyfikacji swoich wysiłków w procesie wychowania dziecka z niepełnosprawnością. Podobna konfiguracja zmiennych pojawia się $w$ modelu regresji o zbliżonej sile predykcji w przypadku zmiennej Satysfakcja z udziału w wychowaniu dziecka [SSIISUW: $\left.\mathrm{F}(6,76)=5,70 ; \mathrm{p}=0,000, \mathrm{R}^{2}=0,31, \mathrm{R}^{2}=0,26\right]$. Słabsze poczucie satysfakcji z poświęcania dziecku z niepełnosprawnością wystarczającej ilości czasu oraz wkładania wysiłku w proces jego wychowania towarzyszy tym matkom, które częściej mają odczucie braku/niedostatku zasobów w swojej roli macierzyńskiej. W ostatnim modelu wymieniony aspekt wymagań, wskazujący na częściej pojawiające sie poczucie niedysponowania wystarczającymi zasobami w roli wraz z doznawaniem sprzeczności w jej realizacji, tworzą dwojakie powiązania z satysfakcją matek z pozarodzinnych form aktywności. Moc wyjaśniania zmienności wariancji zmiennej satysfakcji w tym modelu jest najwyższa [SSIISPFA: $\left.\mathrm{F}(6,76)=6,78 ; \mathrm{p}=0,000, \mathrm{R}^{2}=0,35, \mathrm{R}^{2}=0,30\right]$. Wyższa satysfakcja współwystępuje tutaj z rzadszym poczuciem niedostatku zasobów, ale także z częstszym odczuwaniem sprzeczności w roli matki.

W grupie ojców tylko zmienna Rodzaj niepełnosprawności dziecka tworzy istotne modele regresji dla dwóch aspektów wymagań (szczegółowe dane dostępne u autora). W przypadku zmiennych: Brak wystarczających zasobów w roli oraz Oczekiwania zewnętrzne modele nie były istotne statystycznie. W istotnym modelu dla zmiennej Przeciążenie rolą, wyjaśniającym 18\% wzrostu jej wariancji, częstsze występowanie takiego zjawiska w roli obserwuje się u ojców wychowujących dziecko z niepełnosprawnością intelektualną, w porównaniu do ASD [WR PR: $\mathrm{F}(2,65)=8,21 ; \mathrm{p}=0,000, \mathrm{R}^{2}=0,20$, $\left.\mathrm{R}^{2}=0,17\right]$. Podobnie odnotowano, że ojcowie wychowujący dziecko z NI, w porównaniu do ojców dzieci z ASD, częściej doświadczają sprzeczności $\mathrm{w}$ roli. Istotny model dla tej zmiennej wyjaśnia $12 \%$ zmienności jej wariancji [WR SR: $\mathrm{F}(2,65)=5,74 ; \mathrm{p}=0,005, \mathrm{R}^{2}=0,15, \mathrm{R}^{2}=0,12$ ]. Wszystkie modele regresji, utworzone dla zmiennych satysfakcji, okazały się być istotne i z różną 
siłą wyjaśniają wzrost wariancji zmiennych zależnych. Wymiar satysfakcji, opisujący pozytywne emocje ojców, oraz możliwość realizacji dzięki roli swoich potrzeb psychospołecznych współtworzą istotnie dwa aspekty wymagań, a zakres wyjaśnianej zmienności wariancji tej zmiennej zależnej wynosi 30\%. Ojcowie, częściej mający odczucie niedostatku/braku zasobów w roli oraz rzadziej doświadczający sprzeczności w jej zakresie, doznają słabszej satysfakcji [SSI $\left.\mathrm{F}(6,60)=5,68 ; \mathrm{p}=0,000, \mathrm{R}^{2}=0,36, \mathrm{R}^{2}=0,30\right]$. Wzrost wariancji dla zmiennej satysfakcji $\mathrm{z}$ rozwoju dziecka wyjaśniany w modelu wynosi 35\%. Podobnie jak wcześniej, ojcowie częściej doświadczający niedostatku czy braku zasobów, ale również rzadziej wskazujący na sprzeczności w roli, doznają słabszej satysfakcji $w$ tym obszarze [SSIISRD: $F(6,61)=6,99$; $\left.\mathrm{p}=0,000, \mathrm{R}^{2}=0,41, \mathrm{R}^{2}=0,35\right]$. Istotny model regresji, utworzony dla zmiennej Postawy społeczne, wyjaśnia $26 \%$ wzrostu jej wariancji, a istotny wkład maja tutaj dwa aspekty wymagań. Ojcowie rzadziej doznający sprzeczności w roli, ale również częściej przeciążenia w niej, wykazują niższy poziom satysfakcji ze społecznych postaw wobec własnego dziecka [SSIIPS: $F(6,61)=5,00$; $\left.\mathrm{p}=0,000, \mathrm{R}^{2}=0,33, \mathrm{R}^{2}=0,26\right]$. Istotny wkład zmiennej Sprzeczności w roli odnotowano również $\mathrm{w}$ modelach regresji utworzonych dla pozostałych aspektów ojcowskiej satysfakcji. Modele dla zmiennych Gratyfikacja wysiłków rodzicielskich, Satysfakcja z udziału w wychowaniu dziecka oraz z pozarodzinnych form aktywności wyjaśniają kolejno 30\%, 42\% oraz $43 \%$ wzrostu wariancji zmiennych zależnych. Ojcowie, doznający niższej gratyfikacji podejmowanych wysiłków w toku wychowania dziecka oraz słabszej satysfakcji z dostatecznego w nie zaangażowania, częściej odczuwają brak bądź niedostatek wystarczających zasobów, ale również rzadziej doświadczają sprzeczności $\mathrm{w}$ roli [SSII GWR: $\mathrm{F}(6,61)=5,88 ; \mathrm{p}=0,000, \mathrm{R}^{2}=0,37, \mathrm{R}^{2}=0,30$; SSII SUW: $F(6,61)=9,07 ; p=0,000, R^{2}=0,47, R^{2}=0,42$; SSIISPFA: $F(6,61)=9,27 ; p=0,000$, $\left.\mathrm{R}^{2}=0,48, \mathrm{R}^{2}=0,43\right]$. Ta konfiguracja zmiennych zostaje uzupełniona $\mathrm{w}$ istotnym modelu regresji utworzonym dla satysfakcji z możliwości godzenia roli ojca z innymi o rodzaj niepełnosprawności dziecka [SSIISPFA: $\mathrm{F}(6,61)=9,27$; $\left.\mathrm{p}=0,000, \mathrm{R}^{2}=0,48, \mathrm{R}^{2}=0,43\right]$. Ojcowie, doświadczający niższej satysfakcji, częściej odczuwają brak zasobów w roli, rzadziej doznają w jej zakresie sprzeczności, ale także wychowują dziecko z ASD.

\section{DYSKUSJA}

W toku analiz stwierdzono, że zmienna Wymagania w roli ma istotne znaczenie dla kształtowania wyników rodzicielskiej satysfakcji zarówno w grupie 
matek, jak i ojców, a współtworzone przez nią modele wyjaśniają różny stopień zmienności wariancji zmiennych zależnych. Odnotowano zróżnicowane tendencje w zakresie poszczególnych aspektów wymagań. Większość tych, które osiągają istotność statystyczną w utworzonych modelach, wykazuje ujemne powiązania z satysfakcją, co potwierdza wstępne oczekiwania. Wyjątkiem są doświadczenia sprzeczności w roli matki i ojca, tworzące dodatnie powiązania z satysfakcją, istotne częściej u ojców. W obu grupach, w tym niemal we wszystkich modelach obejmujących zmienne satysfakcji u ojców, oprócz wymienionego aspektu wymagań, istotne ujemne powiązania tworzy zmienna opisująca brak wystarczających zasobów do realizacji roli. W przypadku matek znacząca rola zaznacza się także w tym aspekcie wymagań, jakim są społeczne oczekiwania wobec roli rodzicielskiej. Generalnie można mówić o podobnych tendencjach w grupie rodziców, jeśli chodzi o charakter udziału zmiennej Wymagania w kształtowaniu satysfakcji, a jak dowodzą wstępne analizy między matkami i ojcami, nie różnią się oni istotnie w większości aspektów wymagań oraz satysfakcji. W większości utworzonych modeli zabrakło istotnego udziału zmiennych opisujących rodzaj niepełnosprawności dziecka oraz jego wiek. Te dwie zmienne, a szczególnie rodzaj niepełnosprawności, miały natomiast znaczenie dla kształtowania wyników rodzicielskich wymagań. Zarówno u matek, jak i u ojców wychowanie dziecka z niepełnosprawnością intelektualną, w większym relatywnie zakresie, powoduje częstsze wymagania. Badania porównawcze uwzględniające dzieci z ASD oraz z zespołem Downa, analizujące rodzicielski stres (który nie jest tożsamy $\mathrm{z}$ analizowanymi tu wymaganiami), wykazały, że jego nasilenie może się różnić na niekorzyść jednej bądź drugiej grupy w zależności od obszaru $\mathrm{stresu}^{24}$. Podobne tendencje odnotowano $\mathrm{w}$ innych eksploracjach $\mathrm{z}$ udziałem rodziców dzieci z NI, ASD oraz z niepełnosprawnością ruchową. W niektórych zakresach stresu, analizowanego w obszarze dziecka oraz w obszarze rodzicielskim, różnice przebiegały na niekorzyść NI, w innych - $\mathrm{ASD}^{25}$. Należy wziąć tutaj pod uwagę przede wszystkim poziom funkcjonowania dziecka, w tym jego zdolności komunikacyjne, samodzielność czy występowanie zachowań trudnych. U matek częstość spostrzegania wymagających społecznych oczekiwań związanych z oceną jakości ich roli rodzicielskiej zwiększa się wraz z wiekiem dziecka. Być może wiąże się to $\mathrm{z}$ faktem podjęcia

\footnotetext{
${ }^{24}$ Dąbrowska, Pisula, "Parenting stress and coping styles," 273.

${ }^{25}$ Sara Felizardo, Esperança Ribeiro, Maria J. Amante, "Parental adjustment to disability, stress indicators and the influence of social support," Procedia - Social and Behavioral Sciences 217(2016): 834.
} 
przez dziecko edukacji, kiedy znacznie poszerza się zakres osób, z którymi rodzice powinni współpracować i których oczekiwania w ramach tej współpracy muszą spełniać.

Dokonując bliższego opisu uzyskanych tendencji można stwierdzić, że silniejsze pozytywne doświadczenia, w tym szczęście, duma, spełnienie, satysfakcja, poczucie osobistego rozwoju, wzrostu samooceny, zyskania sensu życia, bycia ważnym dla innych, ponadto większa satysfakcja z możliwości realizowania pozarodzinnych form aktywności, dających także sposobność do odpoczynku od obowiązków rodzicielskich, są powiązane u matek i ojców z częstszym doświadczaniem sprzeczności w roli rodzica. U ojców sprzeczne wymagania, wobec jakich stają $\mathrm{w}$ procesie wypełniania zadań wychowawczych, leczniczych i rehabilitacyjnych, doświadczenia konfliktów, których podstawą jest niespójność przekonań, brak jednoznacznych rozwiązań czy sensu, towarzyszą większej satysfakcji z postępów w rozwoju dziecka, podejmowania wobec niego zadań, które tym postępom służą, silniejszemu doświadczaniu gratyfikacji wysiłków, między innymi dzięki pozytywnym społecznym postawom ukierunkowanym wobec dziecka. Tendencje tutaj opisane nasuwają wniosek, że ten rodzaj rodzicielskich wyzwań, noszących znamiona konfliktów i sprzeczności, wobec których matki i ojcowie przypuszczalnie muszą aktywizować różne strategie zaradcze oraz kompetencje, sprzyja satysfakcji z rodzicielstwa. Wkładany wysiłek, którego skutki są dostrzegane przez rodziców, między innymi w postaci postępów rozwojowych dziecka, pozytywnych ocen ze strony osób znaczących, sprzyja umocnieniu korzystnych doświadczeń postrzeganych $\mathrm{w}$ swojej roli. Bakiera i Stelter ${ }^{26}$ piszą, że zdolność poradzenia sobie przez rodziców z trudnościami może wyzwalać ich potencjał, a rola rodzicielska stwarza możliwość rozwoju. Inni badacze wspominają o rodzicielskiej transformacji pod wpływem określonych, niestandardowych zadań czy nawet ról dostarczających sposobności do sprawdzenia siebie, ale także bogacenia kompetencji ${ }^{27}$.

W przypadku matek słabsze pozytywne doświadczenia emocjonalne oraz przekonania wskazujące na rozwój osobisty, ponadto mniejsza satysfakcja z postępów rozwojowych dziecka i postaw osób znaczących kierowanych wobec niego oraz jego osiągnięć towarzyszą częstszemu dostrzeganiu w środowisku oczekiwań wysokich bądź wygórowanych w stosunku do możliwości, niejasnych, ale także poczuciu stałego podlegania ocenie społecznej. Słabsze

\footnotetext{
${ }^{26}$ Bakiera, Stelter, „Rodzicielstwo z perspektywy rodziców”, 146.

${ }^{27}$ Scorgie, Wilgosh, Sobsey, "The experience of transformation," 85-90.
} 
poczucie bycia docenionymi w swoich rodzicielskich poczynaniach, mniej satysfakcjonujący udział $\mathrm{w}$ rozwoju dziecka czy też mniejsza satysfakcja z możliwości podejmowania pozarodzinnych form aktywności towarzyszy tym matkom, które częściej staja wobec braku zasobów, w tym informacyjnych, czasowych czy kompetencyjnych niezbędnych do podejmowania rodzicielskich zadań. W tym przypadku można sądzić, że sytuacje trudne noszące znamiona deprywacji, naruszające przypuszczalnie obraz siebie jako dobrego rodzica, zwłaszcza w perspektywie społecznych ocen i braku wsparcia, obniżaja poziom rodzicielskiej satysfakcji. Ta tendencja została potwierdzona $\mathrm{w}$ grupie ojców, w nieco innej konfiguracji zmiennych. W ich przypadku oceniana deprywacja zasobów niezbędnych do realizacji roli ojca obniża satysfakcję w poszczególnych ocenianych tu aspektach. Dodatkowo w zakresie satysfakcji z możliwości podejmowania pozarodzinnych form aktywności zostaje ona uzupełniona o występowanie u dziecka zaburzeń ze spektrum autyzmu, które - częściej w porównaniu do NI - zmniejszają nasilenie tej satysfakcji. U ojców także odczucie przeciążenia w roli, powstające w związku z dużą ilością zadań, nie zawsze akceptowanych, wymagających znacznej odpowiedzialności, przekraczających kompetencje, są czynnikiem istotnie obniżającym satysfakcję z postaw, jakie wobec dziecka wyrażają osoby ze środowiska.

Ustalone tu tendencje odbiegają od wyników innych badań, w których analizowano zmienną wieku dziecka czy rodzaj niepełnosprawności. W badaniach rodziców dzieci z zaburzeniami rozwojowymi stwierdzono, że starszy wiek dzieci oraz występowanie ASD są powiązane z mniejszą satysfakcją osobistą rodziców ${ }^{28}$. W badaniach własnych taka tendencja, informująca o znaczącej roli ASD, została potwierdzona jedynie w jednym z aspektów satysfakcji ojców. Należy jednak zauważyć, że ASD współwystępowało z zachowaniami trudnymi dziecka, czego nie analizowano w badaniach własnych. $\mathrm{W}$ jednym z badań jakościowych z udziałem ojców stwierdzono, że w zakresie różnych rodzajów zaburzeń dziecka ojcowie identyfikują podobne korzyści w zakresie jego wychowania ${ }^{29}$. Ponadto zastosowane w eksploracjach wła-

${ }^{28}$ Sayyed Ali Samadi, Ghasem Abdollahi-Boghrabadi, Roy McConkey, "Parental satisfaction with caregiving among parents of children with autism spectrum disorders, attention deficit and hyperactivity, intellectual disabilities and typically developing," Early Child Development and Care 190(2020): 1118; Sayyed Ali Samadi, Ghasem Abdollahi-Boghrabadi, Roy McConkey, "Parental satisfaction with caregiving for children with developmental disabilities: development of a new assessment tool," Children 5(2018), accessed April 10, 2021, DOI: 10.3390/children5120166.

${ }^{29}$ Sheldon, Oliver, Yashar, "Rewards and challenges of parenting a child with Down syndrome," 8. 
snych i cytowanych sposoby ujęcia satysfakcji znacznie się różniły. Zdaniem Bakiery i Stelter ${ }^{30}$ istotą pozytywnych doświadczeń $\mathrm{w}$ roli staje się nie samo dziecko z niepełnosprawnością, ale postępy w jego rozwoju, które stanowią swoisty sukces rodzicielskich poczynań. Ta płaszczyzna satysfakcji była ujęta w badaniach własnych.

\section{ZAKOŃCZENIE}

Przedstawione tu badania dostarczyły informacji na temat pozytywnych i negatywnych doświadczeń rodziców, ujętych w kategoriach wymagań związanych $\mathrm{z}$ rola matki oraz ojca dziecka $\mathrm{z}$ niepełnosprawnością i satysfakcji $\mathrm{w}$ tych rolach. W analizach uwzględniono szereg aspektów składających się na te dwie kategorie, w tym aspekt społecznych oczekiwań i postaw, który może być zarówno źródłem rodzicielskich trudności, jak i zasobów. Pokazano, że w zależności od charakteru wymagań w roli różny może być ich udział w kształtowaniu rodzicielskiej satysfakcji. Rola rodzicielska w sytuacji niepełnosprawności dziecka, także dzięki realizowanym zadaniom i rozwiązywanym problemom sprawdzającym i rozwijającym kompetencje, może być źródłem pozytywnych emocji i przekonań. Wymagania roli mogą również zmniejszać rodzicielską satysfakcję, w tych przypadkach kiedy rodzice nie dysponują wystarczającymi zasobami, kiedy doświadczają nadmiernego obciążenia, zwłaszcza w kontekście dużych wymagań ze strony osób pozostających w ich środowisku. Analiza obu płaszczyzn roli jest tutaj istotna, także z perspektywy praktycznej. Kluczowe znaczenie ma sprawdzanie sytuacji społecznej rodzin, z uwzględnieniem doświadczeń, które z niej wynikają i mogą być ważne dla budowania zasobów w roli bądź też dla obciążeń związanych z jej realizacją. Satysfakcja jest elementem (wskaźnikiem) rodzicielskiego przystosowania i zgodnie ze współczesnymi tendencjami powinna być włączana, obok samooceny, poczucia skuteczności w roli, w badania psychologicznego konstruktu ,pozytywności” ${ }^{31}$.

${ }^{30}$ Bakiera, Stelter, „Rodzicielstwo z perspektywy rodziców”, 147.

${ }^{31}$ Mikeda Jess, Vasiliki Totsika, Richard P. Hastings, "Maternal stress and the functions of positivity in mothers of children with intellectual disability," Journal of Child and Family Studies 27(2018): 3753-3763; Mikeda Jess, Richard P. Hastings, Vasiliki Totsika, "The construct of maternal positivity in mothers of children with intellectual disability," Journal of Intellectual Disability Research 61(2017): 928-938. 
Zrealizowane eksploracje mają kilka ograniczeń, spośród których należy wymienić przede wszystkim stosunkowo nieliczną grupę rodziców, korelacyjny model analiz, nie pozwalający na ujęcie dynamiki zjawisk pozytywnych i negatywnych, ale także specyfikę SES rodziców. Badane matki to osoby pracujące zawodowo, co znacznie odbiega od tendencji obserwowanych w tej grupie, a co może rzutować na jakość doświadczeń w roli rodzicielskiej. W przyszłych badaniach warto uwzględnić udział matek pracujących i nie pracujących. W praktyce bardzo trudno jest spotkać niepełnosprawności proste, bez współwystępujących zaburzeń. Przeprowadzona tu analiza w istocie dotyczyła dwóch sytuacji: występowania niepełnosprawności intelektualnej bez ASD oraz ASD, któremu mogła towarzyszyć NI. Takie analizy, do których włącza się np. osoby z NI czy z zespołem Downa (w zakresie którego może również występować szereg dodatkowych zaburzeń), porównując je z osobami z ASD bądź szerzej - z niepełnosprawnością rozwojową, były prowadzone również przez innych badaczy ${ }^{32}$. Ze względu na potencjalne ograniczenia takiego podejścia przydatne może być włączenie zmiennej Status funkcjonalny dziecka.

Oprócz wskazanych ograniczeń, należy wspomnieć o wkładzie badań własnych, który przejawiał się przede wszystkim, jak można sądzić, w uwzględnieniu matek i ojców dzieci z niepełnosprawnością oraz dwóch perspektyw opisujących jakość pełnionych przez nich ról rodzicielskich.

\section{BIBLIOGRAFIA}

Bakiera, Lucyna, Żaneta Stelter. „Rodzicielstwo z perspektywy rodziców dziecka pełnosprawnego i niepełnosprawnego intelektualnie”. Roczniki Socjologii Rodziny 20(2010): 131-150.

Brown, Theresa J. "Work family conflict among parents of atypically developing children: exploring the impact of worker, work, and child factors." Journal of Child and Family Studies 23(2014): 854-862.

Brown, Theresa J., Kenneth E. Sumner. "Cross national examination of work family in parents of children with disabilities using a bioecological model." Child \& Youth Care Forum 48(2019): 703-718.

32 Dąbrowska, Pisula, "Parenting stress and coping styles," 269; Samadi, Abdollahi-Boghrabadi, McConkey, "Parental satisfaction with caregiving among parents of children with autism spectrum disorders," 3; Samadi, Abdollahi-Boghrabadi, McConkey, "Parental satisfaction with caregiving for children with developmental disabilities," 3; Smith, Romski, Sevcik, Adamson, Barker, "Parent stress and perceptions of language development," 76. 
Cairns, Deborah, Debbie Tolson, Jane Brown, Cris Darbyshire. "The need for future alternatives: an investigation of the experiences and future of older parents caring for offspring with learning disabilities over a prolonged period of time." British Journal of Learning Disabilities 41(2012): 73-82.

Chodkowska, Maria. „Teoria ról społecznych a badania socjopedagogicznych problemów zdrowia i choroby". Chowanna 45(2002): 39-56.

Chouchan, Chandra S., Singh Paramjeet, Kumar Sunil. "Assessment of stress and anxiety in parents of children with intellectual disability." Indian Journal of Health \& Wellbeing 7(2016): 500-504.

Dąbrowska, Anna, Ewa Pisula. "Parenting stress and coping styles in mothers and fathers of pre-school children with autism and Down Syndrome." Journal of Intellectual Disability Research 54(2010): 266-280.

Felizardo, Sara, Esperança Ribeiro, Maria J. Amante. "Parental adjustment to disability, stress indicators and the influence of social support." Procedia - Social and Behavioral Sciences 217(2016): 830-837.

Green, Sara E. „'We're tired, not sad'”: Benefits and burdens of mothering a child with a disability." Social Science \& Medicine 64(2007): 150-163.

Hornby, Garry. "A review of fathers' accounts of their experiences of parenting children with disabilities." Disability, Handicap and Society 7(1992): 363-373.

Jess, Mikeda, Richard P. Hastings, Vasiliki Totsika. "The construct of maternal positivity in mothers of children with intellectual disability." Journal of Intellectual Disability Research 61(2017): 928-938.

Jess, Mikeda, Vasiliki Totsika, Richard P. Hastings. "Maternal stress and the functions of positivity in mothers of children with intellectual disability." Journal of Child and Family Studies 27(2018): 3753-3763.

Johnston, Charlotte, Eric J. Masch. "A measure of parenting satisfaction and efficacy." Journal of Clinical Child Psychology 18(1989): 167-175.

Karney, Penelope M., Tim Griffin. "Between joy and sorrow: being a parent of a child with developmental disability." Journal of Advanced Nursing 34(2001): 582-592.

Kayfitz, Adam D., Marcia N. Gragg, Robert R. Orr. "Positive Experiences of Mothers and Fathers of Children with Autism." Journal of Applied Research in Intellectual Disabilities 23(2010): 337-343.

Knight, Kathryn. "The changing face of the 'good mother': trends in research into families with a child with intellectual disability, and some concerns." Disability \& Society 28(2013): 660-673.

Lee, Yoon-Joo, Hye J. Park, Susan L. Recchia. "Embracing each other and growing together: redefining the meaning of caregiving a child with disabilities." Journal of Child and Family Studies 24(2015): 3662-3675.

Leiter, Valerie, Marty W. Krauss, Betsy , Anderson, Nora , Wells. "The consequences of caring. Effects of mothering a child with special needs." Journal of Family Issuess 25(2004): 379-403.

Meadan, Hedda, Julia B. Stoner, Maureen E. Angell. "Fathers of children with autism: perceived roles, responsibilities and support needs." Early Child Development and Care 185(2015): 1678-1694.

Nelson Goff, Briana S., Kale J. Monk, Juliana, Malone, Staats Natira, Allison Tanner, Nicole P. Springer „Comparing parents of children with Down syndrome at different life span stages." Journal of Marriage and Family 78(2016): 1131-1148.

Niedbalski, Jakub. „Realizowanie ról rodzicielskich i konstruowanie tożsamości rodziców dziecka z niepełnosprawnością intelektualną". Studia Socjologiczne 3(2019): 135-170. 
Nurullah, Abu S. “It's really a roller coaster": experience of parenting children with development al disabilities." Marriage \& Family Review 49(2013): 412-445.

Park, Hye J., Grace H. Chung. "Multifaceted model of changes and adaptation among Korean mothers of children with disabilities." Journal of Child and Family Studies 24(2015): 915-929.

Patric-Ott, Amy, Linda D. Ladd. "The blending of Boss's concept of ambiguous loss and Olshansky's concept of chronic sorrow: a case study of a family with a child who has significant disabilities." Journal of Creativity in Mental Health 5(2010): 73-86.

Potter, Carol A. "'I accept my son for who he is - he has incredible. Character and personality': fathers' positive experiences of parenting children with autism." Disability \& Society 31(2016): 948-965.

Samadi, Sayyed Ali, Ghasem Abdollahi-Boghrabadi, Roy McConkey. "Parental satisfaction with caregiving among parents of children with autism spectrum disorders, attention deficit and hyperactivity, intellectual disabilities and typically developing." Early Child Development \& Care 190(2020): 1115-1122.

Samadi, Sayyed Ali, Ghasem Abdollahi-Boghrabadi, Roy McConkey. "Parental satisfaction with caregiving for children with developmental disabilities: development of a new assessment tool." Children 5(2018), accessed April 10, 2021, DOI: 10.3390/children512 0166.

Schippers, Alice, Michel Berkelaar, Minne Bakker, Geert Van Hove. "The experiences of Dutch fathers on fathering children with disabilities: 'Hey, that is a father and his daughter, that is it." Journal of Intellectual Disability Research 64(2020): 442-454.

Scorgie, Kate, Lorraine Wilgosh, Dick Sobsey. "The experience of transformation in parents of children with disabilities: theoretical considerations." Developmental Disabilities Bulletin 32(2004): 84-110.

Sheldon, Jane P., Mary Oliver, Beverly M. Yashar. "Rewards and challenges of parenting a child with Down syndrome: a qualitative study of fathers' perceptions." Disability and Rehabilitation, accessed April 15, 2021, https://doi.org/10.1080/09638288.2020.1745907.

Sheran, Julia, Stuard Todd. "Maternal employment and family responsibilities: the perspectives of children with intellectual disabilities." Journal of Applied Research in Intellectual Disabilities 13(2000): 109-131.

Sitimin, Shirley A., Amily Fikry, Zulhabri Ismali, Norashikin Hussein. "Work-family conflict among working parents of children with autism in Malaysia." Procedia Computer Science 105(2017): 345-352.

Smith, Ashlyn L., Maryann Romski, Rose A. Sevcik, Lauren B. Adamson, Michael R. Barker. "Parent stress and perceptions of language development: comparing Down Syndrome and other developmental disabilities." Family Relations 63(2014): 71-84.

Stainton, Tim, Hilde Besser. "The positive impact of children with an intellectual disability on the family." Journal of Intellectual and Developmental Disability 23(2008): 57-70.

Takataya, Kumiko, Yoko Yamazaki, Eriko Mizuno. "Perceptions and feelings of fathers of children with Down Syndrome." Archives of Psychiatric Nursing 30(2016): 544-551.

Voydanoff, Patricia. "Implications of work and community resources and demands for marital quality." Journal of Organizational Psychology 9(2004): 275-285.

Zalewska, Anna. Dwa światy. Emocjonalne i poznawcze oceny jakości i ich uwarunkowania u osób o wysokiej i niskiej reaktywności. Warszawa: Academica, 2003. 


\section{SATYSFAKCJA I WYMAGANIA W ROLI MATKI I OJCA DZIECKA Z NIEPEŁNOSPRAWNOŚCIA}

S t r e s z c z e n i e

W artykule zaprezentowano wyniki badań własnych, których celem było ustalenie zależności między wymaganiami roli rodzicielskiej u matek i ojców wychowujących dziecko z niepełnosprawnością a ich satysfakcją z rodzicielstwa. W analizach uwzględniono także wiek dziecka z niepełnosprawnością oraz rodzaj niepełnosprawności. Zastosowano narzędzia własnej konstrukcji w postaci Skali Doświadczeń Rodzicielskich, Skali Wymagań w Roli Rodzicielskiej oraz kwestionariusza ankiety. Ostatecznie wykorzystano materiał uzyskany od 83 matek oraz 67 ojców. Na podstawie wyników analizy regresji wielorakiej stwierdzono podobne tendencje w grupie matek i ojców opisujące udział zmiennej Wzbogacenie w kształtowaniu wyników satysfakcji. Częstsze wymagania roli towarzyszyły najczęściej niższej satysfakcji w jej różnych wymiarach. Jedynie sprzeczności w roli rodzica tworzyły w modelach regresji powiązania dodatnie ze zmienną zależną. Rodzaj niepełnosprawności dziecka był istotny tylko w obszarze kształtowania wyników wymagań roli i jednego z aspektów satysfakcji ojców, z kolei zmienna wieku w zakresie oczekiwań zewnętrznych wobec roli macierzyńskiej.

Słowa kluczowe: role rodzicielskie; rodzicielska satysfakcja; wymagania rodzicielskie; zaburzenia ze spectrum autyzmu; niepełnosprawność intelektualna. 